\title{
Analisis Kinerja Keuangan Pemerintah Kota Bandung Sebelum dan Setelah Mendapatkan Opini WTP dari BPK
}

\author{
Faesal Fazlurahman $^{1)}$, Chandra Fatriananda ${ }^{2)}$, Rifqie Jauhari ${ }^{3)}$ \\ 1), 2), 3) Program Magister Akuntansi Universitas Padjadjaran \\ Jl. Japati No.2, Lebakgede, Kecamatan Coblong, Kota Bandung, Jawa Barat 40132 \\ Email:_fazlurahman8@gmail.com ${ }^{l)}$, chandrafatriananda@gmail.com $^{2}$, rifaie.jauhari@gmail.com $^{3)}$
}

\begin{abstract}
The purpose of this research is to find out the difference on the financial performance of Bandung before and after obtaining an unqualified opinion in terms of regional financial independence, effectiveness of regional income, efficiency of regional income, and growth in regional income. This study uses secondary data in the form of Bandung City government financial reports from 2014 to 2018. The financial performance of the City of Bandung is measured by financial ratios then compared with performance indicators. The results showed that the ratio of independent regional finance, the ratio of effectiveness of regional income, and growth of regional income. Financial performance of Bandung City before and after obtaining a fair opinion without exception has shown a significant improvement, this is evidenced by the increasing ratio of regional independence, and increasing the effectiveness of regional income.
\end{abstract}

Keywords: Financial Performance, Unqualified Opinion, Regional Financial Independence, Regional Income Efficacy, Regional Income Efficiency

\begin{abstract}
ABSTRAK
Tujuan penelitian ini adalah untuk mengetahui apakah terdapat perbedaan dalam kinerja Pemerintah Kota Bandung sebelum dan sesudah mendapatkan opini wajar tanpa pengecualian dalam hal kemandirian keuangan daerah, efektivitas pendapatan daerah, efisiensi pendapatan daerah, dan pertumbuhan pendapatan daerah. Penelitian ini menggunakan data sekunder berupa laporan keuangan pemerintah Kota Bandung dari tahun 2014 sampai 2018. Kinerja keuangan Kota Bandung diukur dengan rasio keuangan kemudian dibandingkan dengan indikator kinerja. Hasil penelitian menunjukkan bahwa rasio independen keuangan daerah, rasio efektivitas pendapatan daerah, dan pertumbuhan pendapatan daerah kinerja keuangan kota bandung sebelum dan sesudah memperoleh opini wajar tanpa pengecualian telah menunjukkan perbaikan yang berarti, hal ini dibuktikan dengan meningkatnya rasio kemandirian daerah, serta meningkatnya Efektivitas pendapatan daerah.
\end{abstract}

Kata Kunci: Kinerja Keuangan, Opini Wajar Tanpa Pengecualian, Kemandirian Keuangan Daerah, Efektivitas Penerimaan Daerah, Efisiensi Penerimaan Daerah

\section{Pendahuluan}

Opini audit adalah hasil penilaian akhir dalam suatu periode dari seorang pemeriksa (auditor) atas pemeriksaan terhadap laporan keuangan yang telah dibuat oleh auditee yang menyatakan tingkat kewajaran atas laporan keuangan yang telah dibuatnya. Hal tersebut merupakan salah satu tanda kepercayaan stakeholders terhadap kesesuaian, relevansi, dan keandalan informasi yang disajikan dalam laporan keuangan. Seiring dengan berkembangnya waktu, opini audit memiliki peranan yang sangat penting yang berkaitan dengan citra pemerintah dimata stakeholders laporan keuangan, seperti DPR/ MPR, investor, dan masyarakat umum. Opini audit dihasilkan dengan didasari oleh fakta-fakta yang ditemukan oleh seorang auditor dalam laporan keuangannya dengan Standar Akuntansi Pemerintahan (SAP) yang telah ditetapkan, serta kepatuhan terhadap perundang-undangan yang berlaku. Dari beberapa opini yang teberikan oleh Badan Pemeriksa Keuangan (BPK), opini Wajar Tanpa Pengecualian (WTP) adalah level opini tertinggi. Selain itu, terdapat pula opini WTP-DPP
(Wajar Tanpa Pengecualian Tanpa Paragraf Penjelasan) dimana WTP-DPP tersebut masih masuk kategori WTP namun untuk pos-pos tertentu diperlukan adanya penyesuaian agar menjadi wajar (Mahmudi, 2007, p. 315). Salah satu poin pentingnya adalah bahwa WTP menjadi tolak ukur transparansi keuangan pusat dan daerah yang dilakukan secara wajar, bebas dari salah saji material serta sesuai dengan peraturan keuangan.

Perkembangan WTP atas dasar hasil audit BPK tahun 2017 menunjukkan bahwa WTP yang didapat oleh LKPD mengalami peningkatan dari 3 LKPD (0,65\%) pada tahun 2016 menjadi 411 LKPD (76\%) pada tahun 2017. Peningkatan kualitas LKPD pada 2017 merupakan upaya yang dilakukan oleh pemda dalam menindaklanjuti temuan dari BPK RI atas ketidaksesuaian dalam peraturan yang berlaku yang terjadi pada tahun 2016. Upaya yang ditempuh diantaranya validasi dan verifikasi berbagai data aset-aset yang belum sepenuhnya tercatat dengan jelas dan baik nilainya. Hal ini menunjukkan adanya kemajuan dalam sistem pengelolaan dan pertanggungjawaban keuangan daerah (LKPD) 
khususnya mengenai pencatatan, pelaporan hingga pertanggungjawaban keuangan daerah oleh pemerintah daerah. Hal tersebut sangat penting untuk diperbaiki guna meningkatkan transparansi dan kehandalan laporan keuangan daerah sehingga dapat memberikan pelayanan yang optimal kepada masyarakat umum. Oleh sebab itu, pemerintah daerah wajib mengelola nggaran yang dikelolanya secara baik dan benar.

Kemandirian daerah dapat diukur dengan pendapatan asli daerah (PAD). Hal tersebut tercermin dari tingkat ketergantungan pemerintah daerah tersebut yang semakin rendah terhadap pemerintah pusat maka semakin besar penerimaan PAD suatu daerah. Selain itu, kemandirian daerah juga mencerminkan kemampuan suatu daerah dalam melaksanakan otonomi daerah dengan memaksimalkan potensi-potensi yang ada dan dikelola sebagaimana mestinya yang nantinya digunakan untuk kemakmuran rakyat.

Dalam kurun waktu 2011 hingga 2017, Pemerintah daerah Kota Bandung sebelumnya belum pernah mendapat opini WTP dari hasil pemeriksaan BPK RI, akan tetapi pada 2018 untuk pertama kalinya Pemerintah daerah Kota Bandung mendapat Opini WTP dari BPK RI atas Laporan Keuangan TA 2018. Disisi yang lain, dalam kurun waktu 2014 hingga 2017 realisasi penerimaan daerah Kota Bandung tidak konsisten cenderung fluktuatif naik dan turun. Hal ini sangat kontras dengan realisasi PAD Kota bandung yang selalu mengalami peningkatan dari tahun 2014 sampai dengan 2018. Agar lebih tergambarkan perbandingannya maka dapat dilihat di Tabel 1 berikut.

Tabel 1. Realisasi PAD dan Penerimaan Daerah

\begin{tabular}{l|rr} 
TAHUN & PENDAPATAN ASLI DAERAH & $\begin{array}{c}\text { TOTAL PENERIMAAN } \\
\text { DAERAH }\end{array}$ \\
\hline $\mathbf{2 0 1 4}$ & 1.716 .057 .298 .000 & 5.302 .471 .399 .000 \\
$\mathbf{2 0 1 5}$ & 1.859 .694 .644 .000 & 5.098 .071 .917 .000 \\
$\mathbf{2 0 1 6}$ & 2.751 .416 .770 .000 & 5.685 .213 .859 .000 \\
$\mathbf{2 0 1 7}$ & 3.065 .143 .012 .000 & 6.503 .784 .683 .000 \\
$\mathbf{2 0 1 8}$ & 3.397 .309 .517 .000 & 6.672 .618 .474 .000
\end{tabular}

Sumber: Data BPS 2014-2018

Suatu pemerintah daerah Kabupaten/ Kota yang mendapat opini WTP idealnya ada pembenahan dari sistem pengelolaan dan pertanggungjawaban keuangannya. Pembenahan sistem pengelolaan dan pertanggung jawabannya tersebut juga harus mengkaji dari siklus pengelolaan keuangan awal sampai dengan akhir yaitu perencanaan, pelaksanaan, pelaporan, dan evaluasi. Atas dasar uraian tersebut, maka peneliti dapat merumuskan permasalahannya yaitu bagaimana kinerja keuangan dari Pemda Kota Bandung sebelum serta sesudah memperoleh opini Wajar Tanpa Pengecualian (WTP).

\section{Landasan Teori}

\subsection{Laporan Keuangan}

Laporan keuangan adalah tanda pertanggung jawaban dari suatu entitas atas pengelolaan sumber daya keuangan entitas. Laporan yang dipublikasikan disusun sesuai dengan prinsip akuntansi sehingga neraca untuk periode sebelumnya atau neraca perusahaan lain dapat dibandingkan. Pelaporan keuangan merupakan produk terakhir dari prosedur akuntansi. Catatan sebelum definisi laporan keuangan, persyaratan akuntansi awal dari pendapat ahli tertentu yang dapat digunakan kinerja, (Weygandt, Kieso, \& Kell, 1996, p. 180) menunjukkan bahwa akuntansi adalah proses dari tiga kegiatan: mengidentifikasi, merekam, dan mengomunikasikan peristiwa ekonomi organisasi (komersial atau sebaliknya) kepada pengguna informasi yang tertarik. Akuntansi didefinisikan sebagai seni menangkap, mengklasifikasikan, dan menyintesis peristiwa, daripada membiayainya, setidaknya sebagian, secara ketat dan dengan penunjuk atau uang serta menafsirkan masalah yang muncul (Munawir, 2002). Sedangkan menurut Horngren Akuntansi adalah sistem informasi untuk mengukur aktivitas bisnis, melaporkan dan melaporkan hasil kepada pembuat keputusan (Horngren, Harrison, \& Bamber, 2002, p. 227).

Dari uraian definisi para ahli, dapat dikatakan proses akuntansi, serangkaian transaksi / peristiwa dan peristiwa keuangan diidentifikasi, dicatat dan diklasifikasikan secara berkala dan dalam bentuk laporan keuangan dilaporkan, yang kemudian digunakan untuk mengevaluasi proses tersebut. pengambilan keputusan untuk pemangku kepentingan di divisi terkait. Akuntansi mengatur dan merangkum informasi bisnis sehingga pengambil keputusan dapat menggunakannya. Informasi ini diberikan dalam bentuk laporan keuangan. Tindakan terakhir dari proses akuntansi adalah penyusunan laporan keuangan tahunan. Laporan keuangan adalah hasil dari proses akuntansi, yang dapat memberikan informasi tentang status kegiatan, serta alat komunikasi antara data keuangan dan pemangku kepentingan dengan data (Munawir, 2002).

Dalam penjelasan yang dijelaskan, laporan keuangan yang dihasilkan dari proses akuntansi menjalin hubungan antara perusahaan dan pihak-pihak yang berkepentingan, memberikan informasi yang berguna kepada para pihak untuk mengetahui status dan perkembangan perusahaan yang dimaksud. Laporan keuangan merupakan laporan atas anggaran tahunan, yang dalam istilah moneter, menyediakan perusahaan seperti informasi untuk membantu orang membuat keputusan informasi (Horngren et al., 2002).

Laporan keuangan adalah sarana utama untuk mengkomunikasikan informasi keuangan ke masalahmasalah non-bisnis (Weygandt et al., 1996). Laporan ini menyajikan sejarah perusahaan, diukur dalam bentuk uang. Laporan keuangan biasanya disajikan dalam bentuk berikut: 1) neraca, 2) laporan laba rugi, 3) laporan arus kas dan 4) laporan pemegang saham atau ekuitas. Selain itu, CALK merupakan bagian yang tidak terpisahkan dari laporan keuangan dari suatu entitas.

Dari definisi di atas, dapat dikatakan jika laporan keuangan merupakan hasil dari proses pelaporan keuangan kuantitatif-kuantitatif, informasi tentang posisi keuangan perusahaan selama periode tertentu dapat membantu pemangku kepentingan membuat keputusan. Ini adalah aturan neraca, laporan laba rugi, laporan perubahan ekuitas, laporan arus kas dan CALK. 


\subsection{Kinerja}

Menurut wirawan telah berpendapat bahwa kinerja adalah hasil yang telah dihasilkan melalui fungsi-fungsi dari pekerjaan atau suatu keahlian dalam jangka waktu tertentu (Wirawan, 2012). Apabila dilihat keterangan diatas maka dapat dikatakan bahwa kinerja adalah suatu hasil yang dikerjakan oleh para pegawai dari pemerintahan melalui fungsi-fungsi dari pekerjaan yang telah ditentukan dalam waktu yang tepat dengan sasaransasaran yang telah ditentukan sebelumnya oleh aparatur pemerintah.

Kinerja adalah tingkat keberhasilan dari seseorang secara keseluruhan selama periode tertentu dalam melaksanakan tugas dibandingkan dengan standar, seperti standar hasil, target, sasaran atau kinerja yang telah ditentukan terlebih dahulu dan telah disepakati bersama (Rivai \& Basri, 2005). Di pihak lain kinerja dapat diartikan sebagai tanda kesediaan individu maupun kelompok dalam menyelenggarakan suatu kegiatan sesuai dengan tanggungjawabnya dan menghasilkan sesuatu yang telah diharapkan. Namun bila dihubungkan dengan performance sebagai kata benda (noun), definisi performance ialah hasil yang telah diperoleh individu atau kelompok orang dalam suatu entitas sesuai dengan hak dan kewajiban dari tiap-tiap pihak dalam mengusahakan hal yang ingin dicapai atas tujuan entitas secara sah, tidak ada pelanggaran hukum dan tidak bertentangan dengan etika.

Dalam manajemen program, Pengukuran kinerja memiliki peranan penting dalam secara keseluruhan, karena dalam meningkatkan keberhasilan pencapaian kinerja maka kinerja tersebut harus terukur. Bastian menegaskan pengukuran kinerja merupakan suatu cara agar menaikan kualitas dalam membuat keputusan dan pertanggungjawaban. Akuntabilitas bukan hanya berkaitan dalam kemampuan menggambarkan bagaimana dana publik dibelanjakan secara ekonomis, efisien, efektif. Sistem pengukuran kinerja pada sektor publik merupakan suatu sistem yang mempunyai tujuan agar pimpinan publik dapat menilai pencapaian dari strategi dengan menggunakan alat ukur baik alat ukur keuangan dan non keuangan. Dalam aspek keuangan, Pengukuran kinerja dapat diukur antara anggaran dengan realisasinya diperbandingkan. Sedangkan dalam aspek non keuangan, pengukuran kinerja dapat diukur dengan melihat pelaksanaan fungsi-fungsi manajerial seperti Perencanaan, Pemeriksaan, Pengkoordinasian, Penilaian, serta Pengawasan.

\subsection{Pengertian Kinerja Keuangan}

Kinerja bisnis dapat digambarkan sebagai upaya formal yang dilakukan oleh perusahaan untuk menilai efisiensi dan efektivitas kegiatan Perusahaan selama periode waktu tertentu. Pengertian kinerja keuangan adalah "penentuan langkah-langkah spesifik yang dapat mengukur keberhasilan suatu organisasi atau perusahaan dalam menghasilkan laba"(sucipto, 2003).

Pengukuran kinerja didefinisikan sebagai "pengukuran kinerja", yaitu kualifikasi, efisiensi dan efektivitas perusahaan dalam manajemen perusahaan selama periode penagihan. Konsep kinerja karena itu merupakan upaya formal oleh perusahaan untuk menilai efisiensi dan efektivitas kegiatan yang dilakukan oleh perusahaan dalam periode tertentu (Hanafi \& Halim, 2007).

Evaluasi kinerja adalah "penentuan efektivitas operasi, organisasi dan personil atas dasar tujuan, standar dan kriteria yang ditetapkan secara teratur" (Srimindarti, 2006). Ada dua jenis kinerja, kinerja operasional dan keuangan. Kinerja operasional lebih fokus pada kepentingan perusahaan seperti kinerja cabang/perusahaan dalam hal kecepatan dan disiplin. Sedangkan keunggulan finansial lebih difokuskan pada evaluasi neraca perusahaan dalam periode dan periode tertentu.

Dalam menentukan kinerja keuangan entitas secara umum, diperlukan analisis atas laporan keuangan tahunan yang menurut (Brigham \& Joel F. Houston, 2013, p. 78) (1), membandingkan kinerja dengan perusahaan lain di sektor yang sama dan (2) ) tren mata uang dari posisi keuangan perusahaan dari waktu ke waktu termasuk. Laporan keuangan tahunan perusahaan memberikan informasi tentang posisi perusahaan pada waktu tertentu dan aktivitas bisnisnya pada periode sebelumnya.

Dari uraian tersebut, dapat dikatakan jika kinerja keuangan merupakan segala upaya yang dilakukan oleh suatu entitas untuk melakukan pengukuran atas keberhasilan yang telah dicapai entitas dalam meraih laba, sehingga memiliki prospek, pertumbuhan dan potensi untuk mengenali perkembangan baik perusahaan menggunakan sumber daya yang ada. Dapat dikatakan bahwa perusahaan berhasil setelah standar dan tujuan yang ditetapkan tercapai.

Pengukuran kinerja digunakan oleh suatu entitas dalam meningkatkan operasi mereka dan bersaing dengan entitas lain. Analisis kinerja keuangan adalah proses peninjauan kritis yang meninjau, menghitung, mengukur, menginterpretasikan, dan memberikan solusi bagi keuangan perusahaan untuk periode waktu tertentu.

Kinerja keuangan dapat dievaluasi dengan berbagai alat analisis. Atas dasar teknik ini, analisis keuangan menurut (Jumingan, 2006) dapat dibagi menjadi 8 (delapan) jenis:

1. Analisis komparatif, merupakan cara-cara analisis yang membandingkan laporan keuangan dua atau lebih periode laporan keuangan, menampilkan perubahan baik dalam jumlah (absolut) dan persentase (relatif).

2. Analisis tren (trend positional), cara-cara analisis dalam, mengetahui apakah tren posisi keuangan telah meningkat atau menurun.

3. Analisis persentase menurut komponen (dimensi umum) adalah cara-cara analisis yang mengukur persentase investasi dalam setiap aset dalam total aset atau dalam total aset atau liabilitas.

4. Analisis sumber dan penggunaan modal kerja, caracara analitik dalam menentukan tingkat sumber dan penggunaan modal kerja dalam dua periode komparatif. 
5. Analisis sumber dan penggunaan kas adalah caracara analisis untuk menentukan status kas sambil mengubah likuiditas selama periode waktu tertentu.

6. Analisis laporan keuangan adalah cara-cara analisis keuangan yang memungkinkan untuk menentukan secara individual dan simultan hubungan antara item-item tertentu dari neraca dan laporan laba rugi.

7. Analisis perubahan laba kotor adalah cara-cara analisis dalam menentukan posisi laba dan penyebab perubahan pendapatan.

8. Break Even Analysis adalah cara-cara analisis dalam menentukan persentase penjualan yang mesti dicapai agar perusahaan tidak menderita kerugian.

Penilaian atas kinerja dari Pemerintah daerah dalam pengelolaan keuangannya, dengan dilakukannya mempergunakan cara-cara rasio keuangan pada laporan keuangan Pemerintah daerah. Hasil analisis rasio keuangan selanjutnya dipergunakan sebagai tolak ukur dalam menilai (Halim, 2007):

1. Rasio Kemandirian Keuangan Pemda

Kemandirian keuangan pemda dapat menggambarkan kemampuan pemda kaitannya dalam mendanai tugas pemerintahan, pembangunan dan pertumbuhan ekonomi serta memberikan layanan pada masyarakat yang telah membayarkan kewajiban pajaknya yang menjadi sumber pendapatannya. Kemandrian keuangan daerah dapat ditandai oleh besar dan kecilnya atas pendapatan asli daerah diperbandingkan dengan total penerimaan daerah.

$$
\text { Rasio Kemandirian }=\frac{\text { Penerimaan Asli Daerah }}{\text { Total Penerimaan Daerah }}
$$

Rasio Kemandirian menggambarkan ketergantungan daerah atas dana yang diperoleh dari luar. Semakin tinggi tingkat rasio kemandirian bermakna kalau kebergantungan pemerintah daerah atas bantuan pihak eksternal dalam hal ini pemerintahan pusat dan pemerintahan provinsi makin rendah, dan terjadi juga sebaliknya. Tingkat rasio kemandirian dapat digambarkan dengan partisipasi dari masyarakat dalam kontribusinya atas pembangunan daerah tersebut. Makin tinggi tingkat rasio kemandirian, maka partisipasi masyarakat makin tinggi dalam membayar kewajiban pajaknya yang merupakan andalan utama dalam penerimaan pendapatannya. Makin tinggi masyarakat dalam membayar kewajiban pajaknya maka dapat menunjukan kesejahteraan masyarakat meningkat.

\section{Rasio Efektivitas Pendapatan Asli Daerah}

Ulum (2009) berpendapat bahwa rasio efektivitas dapat menunjukan kemampuan dari pemda dalam hal merealisasikan pendapatan asli daerahnya diperbandingkan dengan target PAD yang telah ditetapkan atas dasar potensi riil daerah. Makin tinggi rasio efektivitas dari PAD maka makin baik kinerja pemerintah daerahnya.

$$
\text { Rasio Efektivitas }=\frac{\text { Realisasi Penerimaan Asli Daerah }}{\text { Target Penerimaan Asli Daerah }}
$$

3. Rasio Efisiensi Pendapatan Asli Daerah

Alat analisis rasio efisiensi merupakan suatu rasio yang dapat menunjukan perbandingan besarnya biaya yang dikeluarkan untuk memperoleh pendapatan dengan realisasi pendapatan yang diterima (Ulum, 2009). Dalam efisiensi ini erat hubungannya mengenai keluaran dalam bentuk barang atau dengan layanan yang dihasilkan dengan suatu sumber daya yang telah dipergunakan dalam menghasilkan sebuah keluaran. Pemungutan pendapatan yang dilakukan oleh pemerintah dikatakan efisien jika rasio di bawah 100 persen. Apabila semakin kecil rasio efisiensi menandakan bahwa kinerja pemerintah berarti semakin baik. Sangat penting bagi pemerintah daerah untuk menghitung dengan tepat berapa besaran biaya yang dikeluarkan. Karena apabila kinerja pemerintahan ingin semakin baik maka rasio efisiensi harus lebih kecil.

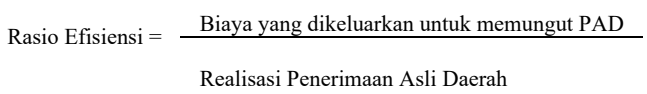

4. Rasio Pertumbuhan Pendapatan Asli Daerah

Rasio Pertumbuhan (Growth Ratio) dapat mengukur besaran kemampuan dari pemerintah daerah dalam meningkatkan keberhasilan pemungutan pendapatan asli daerah yang telah dicapai dari satu periode ke periode yang lainnya (Ekawarna, Sam, \& Rahayu, 2009). Karena semakin besar rasio pertumbuhan pendapatan asli daerah maka menunjukkan bahwa pendapatan asli daerah yang telah diterima oleh pemerintah daerah berarti mengalami peningkatan. Rasio pertumbuhan dapat dirumuskan sebagai berikut.

$$
\text { Rasio Pertumbuhan PAD }=\frac{\text { Realisasi PAD Xn-Realisasi PAD Xn-1 }}{\text { Realisasi Penerimaan PAD Xn-1 }}
$$

\section{METODOLOGI}

Jenis penelitian dapat dikatakan sebagai penelitian kuantitatif yang digunakannya model analisis berupa studi komparatif. Penelitian dilakukan dengan melakukan analisis atas Iaporan keuangan Kota Bandung yang telah audit oleh BPK. Laporan yang akan dibandingkan yaitu laporan keuangan periode tahun anggaran dari 2014 sampai dengan tahun anggaran 2019.

Pemerintah Kota Bandung pertama kalinya mendapatkan Opini wajar tanpa pengecualian (WTP) pertama kali pada laporan keuangan tahunan 2018. Atas laporan keuangan Kota Bandung ini nantinya diukur dengan rasio yang mampu menilai capaian kinerja keuangan Pemerintah Kota Bandung.

Analisis rasio ini dapat digunakan sebagai ukuran penilaian kinerja Pemda. Kemudian diperbandingkan agar menghasilkan hasil apakah ada bedanya kinerja pemerintah daerah sebelum serta setelah mendapatkan opini wajar tanpa pengecualian (WTP) dari Badan Pemeriksa Keuangan.

Hasil dari kinerja yang telah dihitung dengan rasiorasio keuangan yang telah ditentukan tersebut nantinya akan dibandingkan dengan indikator-indikator rasio. 
Analisis kinerja pemda Kota Bandung sebelum serta setelah memperoleh opini wajar tanpa pengecualian (WTP) berbeda atau tidak akan ditentukan oleh indikator indikator tersebut.

\section{Pembahasan}

4.1 Tingkat Kemandirian Keuangan Kota Bandung Dari hasil olah data yang dilakukan oleh peneliti, rasio kemandirian keuangan Kota Bandung dapat dilihat sebagai berikut ini.

Tabel 2. Rasio kemandirian keuangan Kota Bandung Tahun 2014-2018

\begin{tabular}{r|llll} 
TAHUN & $\begin{array}{c}\text { PENERIMAAN } \\
\text { ASLI DAERAH }\end{array}$ & $\begin{array}{c}\text { TOTAL } \\
\text { PENERIMAAN } \\
\text { DAERAH }\end{array}$ & $\begin{array}{c}\text { RASIO } \\
\mathbf{( \% )}\end{array}$ & KETERANGAN \\
\hline $\mathbf{2 0 1 4}$ & $\mathrm{Rp} 1,716,057,298$ & $\mathrm{Rp} 4,953,940,629$ & 34.64 & Rendah \\
$\mathbf{2 0 1 5}$ & $\mathrm{Rp} 1,859,694,644$ & $\mathrm{Rp} 5,098,071,917$ & 36.48 & Rendah \\
$\mathbf{2 0 1 6}$ & $\mathrm{Rp} 2,152,755,704$ & $\mathrm{Rp} 5,685,213,859$ & 37.87 & Rendah \\
$\mathbf{2 0 1 7}$ & $\mathrm{Rp} 2,579,256,279$ & $\mathrm{Rp} 5,735,805,507$ & 44.97 & Rendah \\
$\mathbf{2 0 1 8}$ & $\mathrm{Rp} 3,397,309,518$ & $\mathrm{Rp} 6,672,618,474$ & 50.91 & Sedang
\end{tabular}

Atas dasar tabel 2 diatas, peneliti dapat membuat simpulan bahwa tingkat kemandirian Kota Bandung masih rendah. Rasio kemandirian paling rendah terjadi di tahun 2014 yaitu dengan persentase sebesar 34,64\% sedangkan rasio kemandirian paling tinggi terjadi di tahun 2018 yaitu sebesar 50,91\%. Hal ini disebabkan pendapatan yang diterima oleh Pemda Kota Bandung yang berasal dari Dana Perimbangan yang semakin besar diimbangi dengan kontribusi penerimaan dari Pendapatan Asli Daerah.

Tingkat kemandirian PAD Pemerintah Kota Bandung setelah memperoleh WTP yaitu tahun 2018 lebih baik jika dibandingkan dengan tingkat kemandirian sebelum memperoleh opini WTP. Setelah memperoleh opini WTP, tingkat kemandirian PAD Pemda Kota Bandung sebesar 50,91\% atau naik bila dibandingkan dengan sebelum memperoleh opini WTP yakni sebesar 44,97\%. Kondisi ini menunjukkan bahwa setelah memperoleh opini WTP tingkat kemandirian PAD Kota Bandung mengalami perbaikan.

\subsection{Efektivitas Pendapatan Asli Daerah Kota Bandung \\ Berikut ini Tabel 3 yang merupakan hasil} perhitungan rasio Efektivitas pendapatan asli daerah Kota Bandung, yaitu.

Tabel 3. Rasio Efektivitas Pendapatan Asli Daerah Kota Bandung

\begin{tabular}{c|ccccc} 
TAHUN & REALISASI PAD & TARGET PAD & $\begin{array}{c}\text { RASIO } \\
\text { (\%) }\end{array}$ & KETERANGAN \\
\hline $\mathbf{2 0 1 4}$ & $\mathrm{Rp} 1,716,057,298,380$ & $\mathrm{Rp} 1,808,509,055,075$ & 94.89 & cukup efektif \\
$\mathbf{2 0 1 5}$ & $\mathrm{Rp} 1,859,694,643,510$ & $\mathrm{Rp} 2,066,246,830,526$ & 90.00 & cukup efektif \\
$\mathbf{2 0 1 6}$ & $\mathrm{Rp} 2,152,755,704,000$ & $\mathrm{Rp} 2,767,404,903,364$ & 77.79 & kurang efektif \\
$\mathbf{2 0 1 7}$ & $\mathrm{Rp} 2,579,256,279,200$ & $\mathrm{Rp} 3,015,836,590,302$ & 85.52 & kurang efektif \\
$\mathbf{2 0 1 8}$ & $\mathrm{Rp} 3,397,309,517,811$ & $\mathrm{Rp} 2,640,000,000,000$ & 128.69 & sangat efektif
\end{tabular}

Atas dasar tabel 3 diatas, dapat disimpulkan bahwa rasio Efektivitas pendapatan asli daerah pada tahun 2014 s.d 2015 tergolong cukup efektif. Namun, pada tahun 2016 hal tersebut justru menurun menjadi kurang efektif, hal itu dikarenakan sumbangan yang ditetapkan atas target yang telah ditetapkan kurang dari 80\%. Anggaran pendapatan asli daerah yang kurang efektif ini dapat disebabkan karena anggaran pendapatan asli daerah yang telah ditetapkan ketinggian dan melewati realisasi pendapatan asli daerah pada tahun tersebut.

Efektivitas PAD pada tahun 2017 mengalami peningkatan menjadi $85,52 \%$ atau berada pada rentang 75\%-89\%, namun secara keseluruhan Efektivitas PAD tahun 2017 masih kurang efektif. Efektivitas PAD pada tahun 2018 mengalami peningkatan yang sangat signifikan seiring dengan diperolehnya opini WTP dari BPK RI atas Laporan Keuangan Kota Bandung tahun 2018, semula $85,52 \%$ menjadi $128,69 \%$. Kondisi ini menunjukkan bahwa kinerja Pemkot Bandung dalam hal Efektivitas sebelum dan sesudah memperoleh WTP mengalami perbaikan yang signifikan. Salah satu penyebabnya adalah adanya perbaikan tata kelola pemerintahan dan realisasi PAD yang lebih tinggi dari anggaran PAD.

\subsection{Rasio Efisiensi Pendapatan Asli Daerah}

Analisis laporan keuangan selanjutnya adalah rasio efisiensi pendapatan asli daerah. Atas dasar data sekunder yang ada maka dapat diketahui rasio untuk efisiensi pendapatan asli daerah sebagai berikut:

\begin{tabular}{c|cccc}
$\begin{array}{c}\text { Tabel 4. Rasio Efisiensi Pendapatan Asli Daerah } \\
\text { TAHUN }\end{array} \begin{array}{c}\text { BIAYA } \\
\text { PEMUNGUTAN }\end{array}$ & $\begin{array}{c}\text { PENERIMAAN } \\
\text { ASLI DAERAH }\end{array}$ & RASIO (\%) & KETERANGAN \\
\hline \multicolumn{7}{c}{ PAD } & & & \\
\hline $\mathbf{2 0 1 4}$ & $\mathrm{Rp} 85,096,908,900$ & $\mathrm{Rp} 1,716,057,298,380$ & 4.96 & sangat efisien \\
$\mathbf{2 0 1 5}$ & $\mathrm{Rp} 88,504,920,165$ & $\mathrm{Rp} 1,859,694,643,510$ & 4.76 & sangat efisien \\
$\mathbf{2 0 1 6}$ & $\mathrm{Rp} 104,263,971,550$ & $\mathrm{Rp} 2,152,755,704,000$ & 4.84 & sangat efisien \\
$\mathbf{2 0 1 7}$ & $\mathrm{Rp} 122,325,866,498$ & $\mathrm{Rp} 2,579,256,279,200$ & 4.74 & sangat efisien \\
$\mathbf{2 0 1 8}$ & $\mathrm{Rp} 166,610,166,576$ & $\mathrm{Rp} 3,397,309,517,811$ & 4.90 & sangat efisien
\end{tabular}

Tingkat efisiensi PAD Kota Bandung pada tahun anggaran 2014-2018 diuraikan pada pembahasan berikut ini:

1. Pada tahun 2014, rasio efisiensi PAD Kota Bandung sebesar $4.96 \%$. Hal ini menunjukkan bahwa pada tahun 2014 tingkat efisiensi PAD Koba Bandung mencapai tingkat yang sangat efisien. Efisiensi tersebut menunjukkan bahwa Kota Bandung dalam memperoleh PAD telah berhasil menekan biaya yang dikeluarkan. Biaya pemungutan PAD pada tahun 2014 sebesar Rp 85,096,908,900 atau 4.96\% dari total PAD yang terealisasi yaitu sebesar Rp Rp1,716,057,298,380.

2. Pada tahun 2015, rasio efisiensi PAD Kota Bandung sebesar $4,76 \%$ atau turun sebesar $0,20 \%$ dari tahun 2014 sehingga pada tahun ini kinerja keuangan Kota Bandung atas dasar rasio efisiensi PAD tergolong sangat efisien karena berada dalam kisaran di bawah $10 \%$. Biaya pemungutan PAD pada tahun ini sebesar Rp 88,504,920,165 atau mengalami kenaikan sebesar $3.85 \%$ dari biaya pemungutan PAD yang dikeluarkan pada tahun 2014. Meskipun mengalami peningkatan dalam biaya pemungutan PAD, realisasi PAD pun mengalami peningkatan sebesar 
Rp143,637,345,130 atau sebesar 8.37\% dari Penerimaan Asli Daerah di tahun 2014.

3. Pada tahun 2016, rasio efisiensi PAD Kota Bandung sebesar $4.84 \%$ atau meningkat sebesar $0,08 \%$ dari tahun 2015. Meskipun mengalami peningkatan akan tetapi untuk tahun tersebut rasio efisiensi PAD kota bandung masih tergolong sangat efisien karena berada dalam kisaran di bawah 10\%. Biaya pemungutan PAD pada tahun ini Rp 104,263,971,550 atau mengalami kenaikan sebesar $15.11 \%$ dari biaya pemungutan PAD yang dikeluarkan pada tahun 2014. Hal ini pun berbanding lurus dengan realisasi Penerimaan Asli Daerah dimana pada tahun 2016 realisasi untuk PAD adalah sebesar Rp2,152,755,704,000 atau meningkat sebesar Rp293,061,060,490 (15.76\%) dari realisasi PAD tahun 2015.

4. Pada tahun 2017, rasio efisiensi PAD Kota Bandung sebesar $4.74 \%$ atau menurun sebesar $0,10 \%$ dari tahun 2016. Atas dasar besarnya rasio efisiensi PAD tersebut menggambarkan bahwa kinerja keuangan Kota Bandung yang sangat efisien dalam pencapaian realisasi PAD tahun 2017. Biaya yang dikeluarkan hanya sebesar Rp 122,325,866,498 dan PAD yang terealisasi sebesar Rp2,579,256,279,200.

5. Pada tahun 2018, kinerja keuangan Kota Bandung atas dasar rasio efisiensi PAD tergolong sangat efisien. Rasio efisiensi pada tahun ini sebesar 4.90 $\%$ atau mengalami peningkatan sebesar $0,16 \%$ dari tahun 2017 yang berarti bahwa Kota Bandung berhasil melampaui target PAD yang telah ditetapkan dengan menekan biaya pemungutan PAD yang dikeluarkan hanya sebesar Rp $166,610,166,576$ atau $4.90 \%$ dari total realisasi PAD tahun 2018. Dari total PAD tahun 2018 sebesar Rp 3,397,309,517,811, terdapat peningkatan PAD sebesar Rp1,244,553,813,811 atau sebesar 57.81\% dari PAD tahun sebelumnya.

Atas dasar tren selama 5 tahun tersebut tingkat rasio efisiensi Pendapatan Asli Daerah Kota Bandung mengalami fluktuasi, meskipun demikian secara keseluruhan rasio efisiensi PAD Kota Bandung masih tergolong sangat efisien karena berada $<10 \%$. Hal ini menunjukan bahwa program kegiatan yang telah dirancang oleh Pemerintah Kota Bandung untuk menghasilkan PAD dapat dikatakan berhasil.

\subsection{Rasio Pertumbuhan Pendapatan Asli Daerah}

Tabel 5. Rasio Pertumbuhan Pendapatan Asli Daerah

\begin{tabular}{c|cccc} 
TAHUN & PAD XN & PAD XN-1 & RASIO & KETERANGAN \\
\hline 2013 & $\mathrm{Rp} 1,442,755,239,000$ & - & - & \\
2014 & $\mathrm{Rp} 1,716,057,298,380$ & $\mathrm{Rp} 1,442,755,239,000$ & $18.94 \%$ & rendah \\
2015 & $\mathrm{Rp} 1,859,694,643,510$ & $\mathrm{Rp} 1,716,057,298,380$ & $8.37 \%$ & sangat rendah \\
2016 & $\mathrm{Rp} 2,152,755,704,000$ & $\mathrm{Rp} 1,859,694,643,510$ & $15.76 \%$ & rendah \\
2017 & $\mathrm{Rp} 2,579,256,279,200$ & $\mathrm{Rp} 2,152,755,704,000$ & $19.81 \%$ & rendah \\
2018 & $\mathrm{Rp} 3,397,309,517,811$ & $\mathrm{Rp} 2,579,256,279,200$ & $31.72 \%$ & tinggi
\end{tabular}

Tingkat pertumbuhan PAD Kota Bandung pada tahun anggaran 2014-2018 diuraikan pada pembahasan berikut ini.
1. Atas dasar tabel diatas dapat diketahui bahwa rasio pertumbuhan PAD pada tahun 2014 sebesar 18.94\% dengan tahun dasar 2013. PAD pada tahun 2014 naik sebesar Rp273,302,059,380 dari PAD tahun 2013. Pertumbuhan PAD pada tahun 2014 sebesar 18.94\% ini tergolong dalam kategori rendah.

2. Pada tahun 2015, pertumbuhan PAD meningkat sebesar Rp143,637,345,130 atau sebesar 8.37\% dari PAD tahun 2014. Dengan realisasi PAD pada tahun 2015 sebesar Rp1,859,694,643,510. Meskipun pertumbuhan PAD mengalami kenaikan pada tahun 2015 akan tetapi pertumbuhan PAD tergolong dalam kategori sangat rendah karena berada dibawah $10 \%$.

3. Pada tahun 2016, realisasi PAD sebesar Rp2,152,755,704,000. Sehingga dapat dikatakan bahwa terjadi pertumbuhan Pendapatan Asli Daerah sebesar $\mathbf{1 5 . 7 6 \%}$ atau sebesar Rp293,061,060,490 dari realisasi PAD pada tahun 2015. Pada tahun 2016 pertumbuhan PAD tergolong rendah karena berada di kisaran 11\%-20\%.

4. Pada tahun 2017, realisasi PAD sebesar Rp2,579,256,279,200. Sehingga dapat dikatakan bahwa terjadi pertumbuhan Pendapatan Asli Daerah sebesar 19.81\% atau sebesar Rp426,500,575,200 dari realisasi PAD pada tahun 2016. Pada tahun 2017 pun pertumbuhan sebesar 19.81\% masih tergolong dalam pertumbuhan PAD yang rendah karena berada dibawah $20 \%$

5. Pada tahun 2018, pertumbuhan PAD meningkat tajam sebesar Rp818,053,238,611 atau sebesar 31.72\% dari PAD tahun 2017. Dengan realisasi PAD pada tahun 2018 sebesar Rp3,397,309,517,811. Pertumbuhan PAD ini tergolong dalam kriteria pertumbuhan PAD yang tinggi karena berada diatas 30\%.

Kenaikan atas pertumbuhan PAD tersebut lebih disebabkan pada peningkatan retribusi daerah dan pajak daerah. Atas dasar tren pertumbuhan PAD Kota Bandung diatas, maka meskipun mengalami fluktuasi, tetapi apabila di rata-rata maka Pertumbuhan PAD Kota Bandung berada di kisaran 18.92\%/tahunnya. Hal ini menunjukan bahwa Pemerintah Kota Bandung memiliki kemapuan untuk mempertahankan pertumbuhan ekonomi nya setiap tahun. Sehingga dapat dikatakan bahwa kinerja Pemerintah Kota Bandung baik. Menurut (Hanafi \& Halim, 2007) bila pertumbuhan pendapatan tersebut positif dan kecenderungannya (trend) meningkat maka dapat dikatakan bahwa kinerja pendapatan dinilai membaik. Sebaliknya terjadi penurunan kinerja pendapatan bila pertumbuhan negatif. Kondisi di Kota Bandung pun senada dengan apa yang disampaikan Halim.

\section{Kesimpulan}

Atas dasar hasil penelitian pada Pemerintah Daerah Kota Bandung makan dapat disimpulkan yaitu; Pertama, Kemandirian Keuangan Pemerintah Daerah Kota Bandung selama 2014 sampai dengan 2018 mengalami peningkatan namun berada dalam kategori yang tidak 
optimal. Hal tersebut tercermin dalam rasio kemandirian daerah yang masih dibawah $100 \%$. Pemerintah daerah harus mengurangi tingkat ketergantungan keuangan daerah, terutama sumber penerimaan yang berasal dari Dana Alokasi Umum/ Khusus dari pemerintah pusat. Hal tersebut dapat dilakukan dengan cara intensifikasi dan ekstensifikasi sumber pendapatan daerah seperti pajak dan retribusi daerah guna optimalisasi pendapatan asli daerah.

Kedua, efektivitas PAD dalam merealisasikan PAD selama 2014 sampai dengan 2018 mengalami peningkatan dan penurunan, artinya belum adanya kestabilan dalam hal peningkatan efektivitas PAD. Namun, pada 2018 efektivitas PAD engalami lonjakan signifikansi yang tinggi di angka 128,69 yang menunjukkan bahwa pengelolaan PAD telah efektif karena rasio diperoleh diatas $100 \%$.

Ketiga, tingkat efisiensi PAD Kota Bandung termasuk ke dalam kategori sangat efisien. Hal tersebut tercermin dalam periode 2014 sampai dengan 2018 yang menggambarkan bahwa biaya pemungutan PAD lebih kecil dari PAD. Pemerintah Daerah Kota Bandung menekankan efisiensi dalam hal pemungutan biaya PAD seperti biaya operasional perjalana dinas untuk penyuluhan pajak da retribusi daerah.

Keempat, tingkat rasio pertumbuhan PAD Pemerintah Daerah Kota Bandung mengalami stagnasi periode 2014 sampai dengan 2017. Hal tersebut terjadi karena Pemerintah Daerah Kota Bandung belum secara optimal dalam memaksimalkan sumber-sumber pendapatan asli daerahnya. Berkaca dari periode tersebut, pada 2018 Pemerintah Daerah Kota Bandung berhasil mengoptimalkan sumber-sumber pendapatan asli daerah yang berada dalam kisaran 31,72\%. Artinya bahwa dalam hal ini pertumbuhan PAD Pemerintah Daerah Kota Bandung tergolong tinggi.

\section{Daftar Pustaka}

Brigham, E. F., \& Joel F. Houston. (2013). Fundamentals of Financial Management (13th ed.). SouthWestern: Cengage Learning.

Ekawarna, S., Sam, I., \& Rahayu, S. (2009). Pengukuran Kinerja Anggaran Pendapatan dan Belanja Daerah (APBD) Pemerintah Daerah Kabupaten Muaro Jambi. Jurnal Cakrawala Akuntansi, 1(1).

Halim, A. (2007). Akuntansi Sektor Publik: Akuntansi Keuangan Daerah (3rd ed.). Jakarta: Salemba Empat.

Hanafi, M. M., \& Halim, A. (2007). Analisis Laporan Keuangan (Edisi 3). Yogyakarta: UPP STIM YPKN.

Horngren, C. T., Harrison, W. T., \& Bamber, L. S. (2002). Accounting (5th ed.). New Jersey: Prentice Hall.

Jumingan. (2006). Analisis Laporan Keuangan. Jakarta: PT. Bumi Aksara.

Mahmudi. (2007). Analisis Laporan Keuangan Pemerintah Daerah Panduan Bagi Eksekutif, DPRD Dan Masyarakat Dalam Pengambilan Keputusan Ekonomi, Sosial Dan Politik. Yogyakarta: UPP
STIM YKPN.

Munawir. (2002). Analisis Laporan Keuangan (4th ed.). Yogyakarta: Liberty.

Rivai, V., \& Basri, A. F. M. (2005). Performance Appraisal: Untuk Sistem Yang Tepat Untuk Menilai Kinerja Karyawan dan Meningkatkan Daya Saing Perusahaan. Jakarta: PT. Raja Grafindo Persada.

Srimindarti. (2006). Balanced Scorecard Sebagai Alternatif untuk Mengukur Kinerja. Semarang: STIE Stikubank.

sucipto. (2003). Penilaian Kinerja Keuangan. Medan: Fakultas Ekonomi Universitas Sumatera Utara.

Weygandt, J. J., Kieso, D. E., \& Kell, W. G. (1996). Accounting Principles (4th ed.). Hoboken, New Jersey: John Wiley \& Sons Inc.

Wirawan. (2012). Evaluasi:Teori, Model, Standar, Aplikasi, dan Profesi. Jakarta: PT Raja Grafindo Persada. 